\title{
Approach to Learning: What do Students Expect from Lecturers?
}

\author{
Johannes A. Wiid ${ }^{1}$ Michael C. Cant $^{2} \&$ Monique du Bruyn ${ }^{3}$ \\ ${ }^{1,2,3}$ Department of Marketing Retail Management, University of South Africa, South Africa \\ Correspondence: Johannes A Wiid, University of South Arica, South Africa. \\ Email: jwiid@unisa.ac.za
}

Doi: $10.23918 /$ ijsses.v8i1p201

\begin{abstract}
The days where students are exposed to face-to-face and classroom teaching methods alone are long gone; educational institutions must adapt to the changing instructional needs of students. It is expected from tertiary institutions to continually provide quality education even in times of severe uncertainty, disaster, or emergency situations, such as the Covid-19 pandemic where many countries worldwide are in a lockdown state. This has a significant impact on the way students can be instructed, and the approach students take to learning. Two learning approaches emerged from the research findings; learning subject matter only to pass and learning subject matter comprehensively to form understanding. The role that the lecturer plays in the learning process was emphasised and students acknowledge their role as contributing partners in their own learning.
\end{abstract}

Keywords: Teaching Theories, Learning Approach, Deep Learning, Surface Learning, Learning Strategies, ODL Education, South Africa

\section{Introduction}

Teaching and learning in higher education is an interactive system that is dependent on the unique characteristics of students, the nature of the discipline as well as the environment in which learning takes place (Entwistle et al., 2015). Over the past few decades, the educational landscape has changed dramatically. Traditionally the teacher-centred learning environment was characterised by the lecturer being the primary source of information, and the student was in many instances a passive receiver. This approach to education has become obsolete and a radical shift has been made to a more student-centred learning environment, where students are expected to be more active in the learning process and take responsibility for their own learning (Baeten et al., 2016). The learning environment is one of the areas where significant changes have taken place. Technological advances for example made e-learning and blended learning possible. eLearning is the utilisation of electronic technologies to access educational material outside of a traditional classroom. Blended learning combines online educational materials and opportunities for interaction online with traditional place-based classroom methods. It requires both the presence of the student and lecturer.

Received: February 25, 2021

Accepted: March, 28, 2021

Wiid, J.A., Cant, M.C., \& du Bruyn, M. (2021). Approach to Learning: What do Students Expect from Lecturers? International Journal of Social Sciences \& Educational Studies, 8(1), 201-211. 
Despite the changes in the higher education environment; the shift from educator-centred learning to student-centred learning and the use of electronic media, employers are complaining that graduates do not have the required skills for their jobs and are becoming more persistent in their expectations. Public and private sector leaders expect most graduates to be prepared by universities to be directly employable (Kock, n.d). Steed (2018) argues that students are studying courses that offer subject knowledge and employability skills that are in demand. This creates expectations for students.

Singh (2019) posted a question 'Why do we need to study' on the internet. Some of the replies to this question were as follows: "I want good grades"; "Many people not only study for purpose, but also study for knowledge"; "Training in one craft/skill so as to earn livelihood." "studying is mandatory but it is actually a secondary element in our lives as it does not help us earn money, studying does not help us to get a job, studying does not help you to grow a family, studying will never help you live a life"; "studying is just an eligibility certificate with which we go about everywhere".

It is clear from the above that even though institutions offer courses that are in demand, employers are complaining that graduates do not have the precise skills that they need. It is also clear that students are studying at an institution of higher learning for various reasons and thus finding themselves on a continuum of motivation ranging from high expectation, highly motivated and focused to a could not carelessly attitude. Lectures find themselves in an unenviable position to adopt their personal teaching theory to find the right balance between teaching and learning that would enable them to effectively and efficiently impart knowledge and skills that meet the requirements of employers. Failure to do so not only reflect on the lecturer's reputation but ultimately it might damage the institutions grading and brand reputation. This gives rise to the questions: Why do students study and what is their approach to higher learning? What do they expect the form the lecturer?'

In addressing these questions, the literature regarding approaches to learning and personal teaching theories were researched. Approaches to learning and personal teaching theories will be briefly discussed in the sections that follows.

\section{Approaches to Learning}

The concept 'approach to learning' was first coined by Marton and Säljö (1976) during the 1970s and refers to how students undertake specific learning tasks within their course of study. This research provided evidence of qualitative differences in learning and was used to categorise the different levels of understanding shown by students (Entwistle et al., 2015). Studies on the subject, support the initial findings that two approaches to learning exist namely deep and surface learning. (Biggs, 1987; Entwistle, 2000; Gibbs, 1992; Kember, 1996; Marton et al., 1997; Meyer, 1991; Ramsden, 1988; Richardson, 2000; Trigwell \& Prosser, 1991; Vermunt, 1998; Watkins \& Hattie, 1985). Deep learning focuses on learning to understand. With this approach, students intend to engage with the information to develop workable knowledge from the content. Conversely, surface learning is more focused on learning to remember only. With surface learning students will not question the information given to them and merely study to remember the facts (Garrison et al., 2003, p.16; Jarvis et al., 2003, p.72; Lublin, 2003). 


\subsection{Deep Learning Approach}

A deep learning approach is centred on the intention of a student to engage with the information presented and on developing an operational understanding of the concepts presented, which will cultivate value from the content (Lublin, 2003). A deep approach to learning is strongly driven by intrinsic rewards and can be classified by the fact that students have a desire to understand the content as well as be able to associate it with previous knowledge and experiences, and finally, logically argue evidence presented and present findings. The deep approach learner will aim to understand knowledge and construct meaning of how it will fit in with their own experiences (Beattie et al., 1997; Chin \& Brown, 2000; Entwistle \& Ramsden, 2015; Hay, 2007; Marton \& Säljö, 1984; Ramsden, 1988; Webb, 1997).

\subsection{Surface Learning Approach}

The surface approach implies that students are motivated extrinsically and will learn purely to remember facts; that they will accept information given to them without questioning it, and are driven primarily by assessment (Beattie et al., 1997; Chin \& Brown, 2000; Entwistle \& Ramsden, 2015; Hay, 2007; Marton \& Säljö, 1984; Webb, 1997). Students who follow a surface learning approach are generally just motivated to do whatever is required to acquire the qualification (Lublin, 2003).

In the preceding section the focus was on the students' learning approach. Personal teaching theories will be discussed briefly in the section that follows.

\section{Personal Teaching Theories}

Lecturers teach using their own personal teaching theories which are, according to the seminal work of Fox (1993), the transfer, shaping, travelling, growing, and building of knowledge. Each of these theories is briefly highlighted below.

- Transfer theory: As the name indicates, knowledge of information is transferred from the lecturer to the student in its simplest form without any distortions, or alternatively information is broadcast whether it is relevant or not.

- Shaping theory: This theory refers to the process of shaping students to a predetermined pattern. Lecturers that practise this theory see it as the actual shaping of minds or the creation of connections in students' minds.

- Travelling theory: Metaphorically, education is seen as a journey. The lecturer has the experience and is guiding the student through the process of discovery as a travelling companion rather than a lecturer. It is a cooperative learning process and not just a one-way track.

- Growing theory: The personal development of the student on an intellectual and emotional journey is the focus of this theory. The theory is not limited or inhibited by a preconceived idea of a specified outcome since continuous changes are taking place and learning is constantly evolving.

- Building theory: This theory views the student's mind metaphorically as a building site. Theoretical content is transferred to the student and it is the student's responsibility to apply the theoretical content to construct something according to a pre-determined plan. 


\section{Aim and Methodology}

The aim of this study is to explore what students, who are studying at a leading South African institution of higher learning, expect the from the lecturer in terms of the lecturer's personal teaching theory that would aid them in their approach to learning.

To this end, a self-completion questionnaire was developed. Questionnaire items were formulated based on the seminal research of Fox (1993). The questionnaire was piloted with 10 undergraduate students and potential problems were resolved before submitting it to the full sample. The self-developed questionnaire consisted mostly of incorporated questions of a quantitative nature and questions to elicit demographical information. A 7-point Likert scale was selected above a 5-point scale to account for the increased variance in measure without compromising reliability (Casado, 2014). After capturing and cleaning the data, it was analysed by using the statistical analysis package SAS.

The questionnaire was administered to undergraduate students from a leading South African university. In total, 221 correctly completed questionnaires were obtained, with a $6.59 \%$ margin of error at a $95 \%$ confidence level and response distribution of $50 \%$.

Most students were under the age of 30 years $(55.05 \%)$ and the gender split for the respondent group was female dominated at $63 \%$.

\section{Research Findings}

The respondents were presented with a list containing learning approach statements. They were asked to indicate their personal learning approach on a 7-point scale ranging from $1=$ strongly disagree to $7=$ strongly agree. For easy reporting on the items, scale points 1 - 3 (disagree - strongly disagree) were collapsed to form a new category 'disagree'; scale points 5 - 7 (agree - strongly agree) were collapsed to form a category 'agree' and 4 remained neutral. Table 1 shows the results obtained for this question. 
Table 1: Distribution of responses regarding learning approach statements

\begin{tabular}{|c|c|c|c|c|c|c|}
\hline \multirow[t]{2}{*}{ No } & \multirow[t]{2}{*}{ Items } & \multirow{2}{*}{\begin{tabular}{|l|} 
Disagree \\
$\%$ of Total
\end{tabular}} & \multirow{2}{*}{$\begin{array}{c}\text { Neutral } \\
\% \text { of Total }\end{array}$} & \multirow{2}{*}{$\begin{array}{c}\text { Agree } \\
\% \text { of Total }\end{array}$} & \multicolumn{2}{|c|}{ All } \\
\hline & & & & & $\mathrm{N}$ & $\begin{array}{l}\% \text { of } \\
\text { Total }\end{array}$ \\
\hline 1 & $\begin{array}{l}\text { A student development plan does } \\
\text { not need to specify the exact } \\
\text { dimensions and outcomes to } \\
\text { achieve. }\end{array}$ & 52.76 & 14.57 & 32.67 & 199 & 100 \\
\hline 2 & $\begin{array}{l}\text { All parts of learning materials are } \\
\text { components of a higher system } \\
\text { that is interconnected and } \\
\text { meaningful. }\end{array}$ & 20 & 10 & 70 & 200 & 100 \\
\hline 3 & $\begin{array}{l}\text { Attitudes, activities and personal } \\
\text { skills are more important than } \\
\text { detailed knowledge. }\end{array}$ & 29.65 & 21.11 & 49.24 & 199 & 100 \\
\hline 4 & $\begin{array}{l}\text { Exploration of learning material } \\
\text { is a personal activity. }\end{array}$ & 23.12 & 21.61 & 55.28 & 199 & 100 \\
\hline 5 & $\begin{array}{l}\text { If a topic is taught, it will be } \\
\text { learned. }\end{array}$ & 21.93 & 14.29 & 63.78 & 196 & 100 \\
\hline 6 & $\begin{array}{l}\text { Learned content should be } \\
\text { permanent and useful. }\end{array}$ & 14.94 & 11.86 & 73.2 & 194 & 100 \\
\hline 7 & $\begin{array}{l}\text { Training and education are the } \\
\text { same. }\end{array}$ & 44.38 & 16.33 & 39.28 & 196 & 100 \\
\hline 8 & $\begin{array}{l}\text { Lecturers have to develop the } \\
\text { mind and brain of students. }\end{array}$ & 23.74 & 14.14 & 62.12 & 198 & 100 \\
\hline 9 & $\begin{array}{l}\text { Lecturers are there to shape the } \\
\text { minds of students. }\end{array}$ & 19.71 & 11.62 & 68.69 & 198 & 100 \\
\hline 10 & $\begin{array}{l}\text { Lecturers create a possible bridge } \\
\text { between theories and concepts. }\end{array}$ & 15.23 & 9.14 & 75.64 & 197 & 100 \\
\hline
\end{tabular}




\begin{tabular}{|c|c|c|c|c|c|c|}
\hline 11 & $\begin{array}{l}\text { Part of teaching is to deliver } \\
\text { (provide) the study material to the } \\
\text { student. }\end{array}$ & 21.42 & 15.82 & 62.76 & 196 & 100 \\
\hline 12 & $\begin{array}{l}\text { Student success is to be measured } \\
\text { by practical outcome. }\end{array}$ & 13.77 & 18.88 & 67.35 & 196 & 100 \\
\hline 13 & $\begin{array}{l}\text { Students should be closely } \\
\text { monitored with predetermined } \\
\text { outcomes. }\end{array}$ & 19.38 & 21.94 & 58.68 & 196 & 100 \\
\hline 14 & $\begin{array}{l}\text { Students should just study } \\
\text { lecturer's notes. }\end{array}$ & 57.3 & 16.15 & 26.56 & 192 & 100 \\
\hline 15 & $\begin{array}{l}\text { Study material is only significant } \\
\text { in terms of what it does for the } \\
\text { personal growth of the student. }\end{array}$ & 30.21 & 24.48 & 45.32 & 192 & 100 \\
\hline 16 & $\begin{array}{l}\text { Subjects should have large factual } \\
\text { content. }\end{array}$ & 25.92 & 19.69 & 54.41 & 193 & 100 \\
\hline 17 & $\begin{array}{l}\text { Successful learning is a result of } \\
\text { well-prepared material. }\end{array}$ & 12.19 & 10.66 & 77.15 & 197 & 100 \\
\hline 18 & $\begin{array}{l}\text { Teaching and learning is a matter } \\
\text { of creating connections in the } \\
\text { student's minds. }\end{array}$ & 13.92 & 10.31 & 75.77 & 194 & 100 \\
\hline 19 & $\begin{array}{l}\text { Teaching is only an act of } \\
\text { conveying information. }\end{array}$ & 34.87 & 20 & 45.13 & 195 & 100 \\
\hline 20 & $\begin{array}{l}\text { Teaching takes place according to } \\
\text { a predetermined plan. }\end{array}$ & 21.13 & 17.53 & 60.83 & 194 & 100 \\
\hline 21 & $\begin{array}{l}\text { The driving force for learning and } \\
\text { growing is internal and should } \\
\text { come from the learner. }\end{array}$ & 20.91 & 7.14 & 71.93 & 196 & 100 \\
\hline 22 & $\begin{array}{l}\text { The emphasis of teaching should } \\
\text { be on growing the student as a } \\
\text { person. }\end{array}$ & 13.85 & 17.95 & 68.21 & 195 & 100 \\
\hline
\end{tabular}




\begin{tabular}{|l|l|l|l|l|l|l|}
\hline 23 & $\begin{array}{l}\text { The lecturer must guide students } \\
\text { in their learning, as he/she knows } \\
\text { best. }\end{array}$ & 15.38 & 8.72 & 75.9 & 195 & 100 \\
\hline 24 & $\begin{array}{l}\text { The lecturers focus their attention } \\
\text { on knowledge before it is } \\
\text { transferred rather than on the act } \\
\text { of transfer. }\end{array}$ & 14.95 & 19.59 & 65.46 & 194 & 100 \\
\hline 25 & $\begin{array}{l}\text { The student is a contributing } \\
\text { partner in his/her own learning. }\end{array}$ & 14.28 & 5.1 & 80.6 & 196 & 100 \\
\hline
\end{tabular}

As indicated in Table 2 above, based on the highest averages, the item that the respondents mostly agreed with, is item 25: "The student is a contributing partner in his/her own learning" (80.6\%) and the item that the respondents mostly disagreed with is item 14: "Students should just study lecturer's notes" (57.3\%).

\section{Construct Validity of ODL Students}

Principal factor analysis, with varimax rotation and Kaiser normalisation, was performed to examine the construct validity of measures adopted in this study. Factors were requested taking the scree plot, eigenvalues, and percentage of variance as well as the minimum of three items per construct into account. After rotation, the first factor accounted for $32.26 \%$ of the variance and the second for $6.62 \%$. Most factor loadings were 0.4 or above, showing good convergent validity. The constructs are therefore unidimensional and factorially distinct, and all items were used to operationalise a construct's load onto a single factor. Some cross-loadings were experienced as well as a few items (1, 4 and 7$)$ that did not load anywhere.

\section{Reliability of the Sub-constructs}

Reliability is the consistency of the measurement, or the degree to which an instrument measures the same way each time it is used, under the same conditions with the same subjects. Cronbach's alpha values above 0.8 indicate very good reliability, values between 0.6 and 0.8 indicate acceptable reliability, and values below 0.6 indicate unacceptable reliability. Cronbach's alpha for the two sub-constructs all yielded high values ( $>0.8$ ), indicating good reliability. Table 2 below represents the Cronbach's alpha values of each of the two constructs. 
Table 2: Cronbach's alpha

\begin{tabular}{|l|c|c|}
\hline \multicolumn{1}{|c|}{ Sub-construct } & \multicolumn{1}{|c|}{ Items } & Cronbach's alpha \\
\hline Learn subject matter comprehensively & $\begin{array}{l}2,5,6,8,9,10,11,12,13,16, \\
17,18,20,21,22,23,24 \text { and } 25\end{array}$ & 0.93 \\
\hline Learn subject matter only to pass & $3,14,15$ and 19 & 0.61 \\
\hline
\end{tabular}

\section{Importance and Choice of the Learning Approach}

The constructs (are shown as a single value, determined by the mean score of the relevant items relating to the specific construct and each student was categorised by the preferred learning theory. The averages of the constructs on a 7-point scale are as follows: Learn subject matter only to pass - $4.04(\mathrm{~s}=1.38)$ and learn subject matter comprehensively - $5.15(\mathrm{~s}=1.41)$ and most students $(74 \%)$ preferred the 'learn subject matter comprehensively' approach to learning; see Table 3.

Table 3: Learning approach and choice

\begin{tabular}{|l|c|c|c|c|}
\hline \multirow{2}{*}{ Learning approach } & \multicolumn{2}{|c|}{ Importance } & \multicolumn{2}{c|}{ Choice } \\
\cline { 2 - 5 } & Mean & Std Dev & \% of Total & $\mathrm{N}$ \\
\hline Learn subject matter only to pass & 4.04 & 1.38 & $25.98 \%$ & 53 \\
\hline Learn subject matter comprehensively & 5.15 & 1.41 & $74.02 \%$ & 151 \\
\hline & & & $100.00 \%$ & 204 \\
\hline
\end{tabular}

The biographical variables - age, gender, and population group - were tested against the learning theory constructs. NO significant differences in learning theories were found.

\section{Discussion}

A keyword search of Google Scholar and Scopus revealed that education and learning is a well-researched area; however, the novelty search did not yield useful results to the question of what students want from a lecturer. However, several personal characteristics students want in a lecturer were identified. These include, but are not limited to, aspects such as students want a lecturer that engages them in the learning process (Cox, 2017); students want a lecturer who will change them and show and guide them on the subject matter (Imafidon, n.d.). The results of the study confirm these traits or characteristics of a good lecturer in that respondents agreed with items such as "The student is a contributing partner in his/her own learning" and "The lecturer must guide students in their learning as he/she knows best". 
The questionnaire items were subjected to exploratory factor analysis and two factors with acceptable reliability emerged. The first factor indicated that almost three-quarters of the respondents want to 'learn subject matter comprehensively'. Comprehensively implies that they would like to learn everything on the subject, including application. Comprehensive learning would be equivalent to deep-level learning and it encapsulates the personal teaching theories of travelling, growing, shaping, and building. According to Gooblar (2019) and Terada (2019), students perform better in active learning than in low effort learning such as listening to lectures.

The second factor relates to low-level or surface learning: 'learn subject matter only to passes. This implies that the lecturer's personal teaching theory must aid them to do so. The personal teaching theory that applies to this type of learning is transfer theory. Almost a quarter of the respondents preferred the surface approach to learning and transfer as teaching theory.

\section{Conclusions and Recommendations}

The aim was to explore what students, who are studying at a leading South African institution of higher learning, want from the lecturer's personal teaching theory that would aid them in their approach to learning.

Most students want a lecturer that can engage them in the learning process and that is there to support and guide them throughout the learning journey. They want to follow a deep learning approach and lecturers that teach according to personal teaching theories of travelling, growing, shaping, and building. It is recommended that institutional HR practices include and emphasise teaching theories in the recruitment and selection processes. It is important that lecturing staff receive training in online teaching platforms as this will not only lead to improved support, but it will also enable them to impart knowledge and skills effectively and efficiently.

More than a quarter of the students indicated that they prefer to 'learn subject matter only to passes. This implies that a large portion of the student body is only studying for the sake of studying and it can be assumed that these students need direction, focus and motivation. If graduates enter the labour market, and do not have the skills that employers are looking for, it can harm the reputation and brand image of that institution. It is therefore recommended that institutions should provide students with professional services such as aptitude testing, career guidance and counselling. Studying towards a degree that is aligned with interest and aptitude can lead to a more focused and motivated student. To curb learn subject matter only to pass, lectures should focus on continuous interactive assessment practices which will force students to learn and apply subject matter. In doing so students will become more knowledgeable and skilled, thereby enhancing their employability.

Some of the limitations of this research include the fact that only open distance learning students at a public higher learning institution were part of the study, which obviously excludes the opinion of students at a residential institution as well as the private higher education point of view. 


\section{References}

Baeten, M., Dochy, F., Struyven, K., Parmentier, E., \& Vanderbruggen, A. (2016). Student-centred learning environments: an investigation into student teachers' instructional preferences and approaches to learning. Learning Environments Research, 19(1), 43-62.

Beattie IV, V., Collins, B., \& McInnes, B. (1997). Deep and surface learning: a simple or simplistic dichotomy? Accounting Education, 6(1), 1-12.

Biggs, J. B. (1970). Personality correlates of certain dimensions of study behaviour. Australian Journal of Psychology, 22(3), 287-297.

Biggs, J. B. (1987). Student approaches to learning and studying. [Research Monograph.] Australian Council for Educational Research.

Biggs, J. (1999). Teaching for quality learning at university. SRHE and Open University Press.

Casado, N. S. (2014). Should we use a 5- or 7-point Likert scale? What's better and why? https://www.researchgate.net/post/Should_we_use_a_5_or_7_ point_Likert_scale_Whats_better_and_why

Case, J., \& Marshall, D. (2004). Between deep and surface: procedural approaches to learning in engineering education contexts. Studies in Higher Education, 29(5), 605-615.

Chin, C., \& Brown, D. E. (2000). Learning in science: a comparison of deep and surface approaches. Journal of Research in Science Teaching, 37(2), 109-138.

Cox S. (2017). Six traits to help meet students [sic] expectations. https://www.teacherready.org/students-expectations//

Entwistle, N. (2000). Promoting deep learning through teaching and assessment: conceptual frameworks and educational contexts. TLRP Conference, Leicester.

Entwistle, N., \& Ramsden, P. (2015). Understanding student learning. Routledge.

Entwistle, N., Karagiannopoulou, E., Ólafsdóttir, A., \& Walker, P. (2015). Research into student learning and university teaching. In J. M. Case, \& J. Huisman (Eds.), Researching higher education: International perspectives on theory, policy and practice. (pp. 190-208). Routledge.

Fox, D. (1983). Personal theories of teaching. Studies in Higher Education, 8(2), 151-163. https://www.tandfonline.com/doi/abs/10.1080/03075078312331379014

Garrison, D. R., Anderson, T., \& Archer, W. (2003). A theory of critical inquiry in online distance education. Handbook of Distance Education, 1, 113-127.

Gibbs, G. (1992). Improving the quality of student learning: based on the Improving Student Learning Project funded by the Council for National Academic Awards. Technical and Educational Services.

Gooblar, D. (2019). Do students really learn nothing from a lecture? The Chronicle of Higher Education. https://www.chronicle.com/article/Do-Students-Really-Learn/247433

Hay, D. B. (2007). Using concept maps to measure deep, surface and non- learning outcomes. Studies in Higher Education, 32(1), 39-57.

Imafidon, C. (n.d.). 15 things students really want from teachers. https://www.lifehack.org/articles/communication/15-things-students-really-want-fromteachers.html

Jarvis, P., Holford, J., \& Griffin, C. (2003). The theory and practice of learning. Psychology Press.

Kember, D. (1996). The intention to both memorise and understand: another approach to learning? Higher Education, 31(3), 341-354.

Kock,A. n.d. Why study further? https://postgraduate.mandela.ac.za/Why-study-further

Lublin, J. (2003). Deep, surface, and strategic approaches to learning. Centre for Teaching and Learning. 
Marchese, T. (1997). The new conversation about learning. In E. E. Chaffee (Ed.), Assessing impact: evidence and action. Proceedings of the 1997 AAHE Conference on Assessment \& Quality, 79-95. American Association of Higher Education.

Marton, F. (1983). Beyond individual differences. Educational Psychology, 3(3-4), 289-303.

Marton, F., \& Säljö, R. (1976). On qualitative differences in learning: outcome and process. British Journal of Educational Psychology, 46(1), 4-11.

Marton, F., \& Säljö, R. (1984). Approaches to learning. In F. Marton, F. Hounslow, \& N. Entwistle (Eds.), The experience of learning: Implications for teaching and studying in higher education, $\left(3^{\text {rd }}\right.$ ed). University of Edinburgh, Centre for Teaching, Learning and Assesment. https://www.ed.ac.uk/institute-academic-development/learning-teaching/research/experienceof-learning

Marton, F., Hounsell, D., \& Entwistle, N. (1997). The experience of learning: Implications for teaching and studying in higher education. Scottish Academic Press.

Meyer, J. H. F. (1991). Study orchestration: the manifestation, interpretation, and consequences of contextualised approaches to studying. Higher Education, 22(3), 297-316.

McDrury, J. \& Alterio, M. (2003). Learning through storytelling in higher education: Using reflection and experience to improve learning. Routledge.

Prosser, M., \& Trigwell, K. (1999). Understanding learning and teaching: The experience in higher education. SRHE \& Open University Press.

Ramsden, P. (1988). Context and strategy. In R. R. Schmeck (Ed.), Learning strategies and learning styles (pp. 159-184). Springer.

Richardson, J. T. (2000). Researching student learning: Approaches to studying in campus-based and distance education. Open University Press.

Singh. R. 2019. Why do we need to study? https://www.quora.com/Why-do-we-need-to-study

Steed. S. 2018. Too many graduates are mismatched to their jobs. What is going wrong? The Guardian. https://www.theguardian.com/higher-education-network/2018/jan/25/too-many-graduates-aremismatched-to-their-jobs-whats-going-wrong

Trigwell, K., \& Prosser, M. (1991). Improving the quality of student learning: the influence of learning context and student approaches to learning on learning outcomes. Higher Education, 22(3), 251-266.

Terada, Y. (2019). Students think lectures are best, but research suggests they are wrong. https://www.edutopia.org/article/students-think-lectures-are-best-research-suggests-theyrewrong

Vermunt, J. D. (1998). The regulation of constructive learning processes. British Journal of Educational Psychology, 68(2), 149-171.

Watkins, D., \& Hattie, J. (1985). A longitudinal study of the approaches to learning of Australian tertiary students. Human Learning: Journal of Practical Research \& Applications, 4(2), 127-141.

Webb, G. (1997). Deconstructing deep and surface: towards a critique of phenomenography. Higher Education, 33(2), 195-212. 